Anna Piekarskal, Anatol Panasiuk ${ }^{2}$, Piotr M Stępień ${ }^{3}$

\title{
CLINICAL PRACTICE GUIDELINES FOR CLOSTRIDIOIDES (CLOSTRIDIUM) DIFFICILE INFECTION AND FECAL MICROBIOTA TRANSPLANT PROTOCOL - RECOMMENDATIONS OF THE POLISH SOCIETY OF EPIDEMIOLOGY AND INFECTIOUS DISEASES
}

\author{
POSTĘPOWANIE W ZAKAŻENIACH CLOSTRIDIOIDES (CLOSTRIDIUM) DIFFICILE \\ WRAZ Z ZASADAMI TRANSFERU MIKROBIOTY JELITOWEJ \\ - REKOMENDACJE POLSKIEGO TOWARZYSTWA EPIDEMIOLOGÓW \\ I LEKARZY CHORÓB ZAKAŹNYCH
}

\author{
${ }^{1}$ Medical University of Lodz, Department of Infectious Diseases and Hepatology \\ ${ }^{2}$ Regional Hospital named Jędrzej Śniadecki in Białystok, Department of Gastroenterology, \\ Hepatology, and Internal Medicine \\ ${ }^{3}$ Regional Hospital in Kielce and The Jan Kochanowski University in Kielce, Infectious Diseases Department \\ ${ }^{1}$ Uniwersytet Medyczny w Łodzi, Klinika Chorób Zakaźnych i Hepatologii \\ ${ }^{2}$ Wojewódzki Szpital Zespolony im. J. Śniadeckiego w Białymstoku, \\ Oddział Gastroenterologii, Hepatologii i Chorób Wewnętrznych, \\ ${ }^{3}$ Wojewódzki Szpital Zespolony w Kielcach oraz Uniwersytet Jana Kochanowskiego w Kielcach, \\ Klinika Chorób Zakaźnych
}

\begin{abstract}
Symptomatic Clostridium difficile infection (CDI) is an acute inflammatory disease of the gastrointestinal tract, manifesting in at least 3 unformed stools within 24 hours. Predicting factors for CDI include contact with medical care (mainly hospitalization), antibiotic therapy in the last 12 weeks, use of proton pump inhibitors (PPI), H2 blockers, cancer chemotherapy, especially in the neutropenia stage, gastrointestinal surgery, advanced age and concomitant chronic diseases (renal failure, liver failure, chronic inflammatory bowel disease - especially ulcerative bowel disease, cancer, HIV infection, cachexia and hypoalbuminaemia) and vitamin D deficiency. Clinical classification distinguishes three types of CDI - mild / moderate, severe, and fulminant. The principles of treatment of the first and subsequent CDI incidents depending on the clinical course are based on oral vancomycin.

CDI is recurrent. The basis for treating CDI relapses is vancomycin administered orally at a dose of $4 \times 125 \mathrm{mg}$ for 10 days followed by concomitant vancomycin dose reduction therapy.

The use of fecal microbiota transfer (FMT) in the treatment of CDI relapses is considered to be the most effective therapy for recurrent CDI. An indication for FMT is antibiotic-resistant $C$. difficile infection, regardless of the number of incidents CDI. The panel of tests recommended for a bacterial flora donor is presented in the recommendations.
\end{abstract}

Key words: Clostridium difficile infection, fecal microbiota transfer, vancomycin

\section{STRESZCZENIE}

Objawowe zakażenie Clostridium difficile (Clostridium difficile infection, CDI) jest ostrą chorobą zapalną przewodu pokarmowego, manifestującą się co najmniej trzema nieuformowanymi stolcami w ciągu 24 godzin. Czynniki predysponujące do wystąpienia CDI to kontakt z opieką medyczną (głównie hospitalizacja), antybiotykoterapia w ciągu ostatnich 12 tygodni, stosowanie inhibitorów pompy protonowej (IPP), blokerów H2, chemioterapii nowotworów, szczególnie w fazie neutropenii, chirurgia przewodu pokarmowego, podeszły 
wiek i przewlekłe choroby współistniejące (niewydolność nerek, niewydolność wątroby, przewlekłe zapalne choroby jelit - szczególnie wrzodziejące zapalenie jelit, nowotwory, zakażenie HIV, choroby przebiegające z wyniszczeniem i hipoalbuminemią) oraz niedobór witaminy D.

Kwalifikacja kliniczna wyróżnia 3 rodzaje przebiegu CDI - lekki/umiarkowany, ciężki i piorunujący. Zasady leczenia pierwszego i kolejnych incydentów CDI w zależności od przebiegu klinicznego opierają się na stosowaniu wankomycyny doustnie. CDI ma charakter nawrotowy. Podstawą leczenia nawrotów CDI jest wankomycyna stosowana doustnie $\mathrm{w}$ dawce $4 \times 125 \mathrm{mg}$ przez $10 \mathrm{dni}$ z następczym zastosowaniem terapii stożkowej wankomycyną w zmniejszających dawkach.

Zastosowanie transferu flory jelitowej (fecal microbiota transfer, FMT) w leczeniu nawrotów CDI uważa się za najbardziej efektywną terapię nawrotowego CDI. Wskazaniem do wykonania FMT jest oporne na leczenie antybiotykami zakażenie $C$. difficile, niezależnie od liczby incydentów CDI. Panel badań rekomendowanych $\mathrm{u}$ dawcy flory bakteryjnej przedstawiono $\mathrm{w}$ rekomendacjach.

Słowa kluczowe: zakażenie Clostridium, transfer flory jelitowej, wankomycyna

\section{INTRODUCTION}

CDI case definition. Symptomatic Clostridioides (Clostridium) difficile (CDI) infection is an acute inflammatory bowel disease that manifests with at least 3 loose stools per 24 hours (1).

CDI etiology. Clostidioides difficile (CD) is an obligate anaerobic, spore-forming Gram-positive bacterium that produces strong exotoxins (1). Its former name (Clostridium difficile) was changed in 2016 to Clostridioides difficile as it was assigned to a new genus Clostridioides (2). However, for the time being both names can be used interchangeably (3).

Non-toxigenic Clostridioides difficile strains can colonize intestines in neonates and in elderly. In healthy adults Clostridioides difficile does not constitute part of the intestinal microbiota and its presence is strongly suppressed by the normal flora. Use of medications that change the structure of the gut bacterial composition and reduce the quantity of healthy bacteria promotes rapid multiplication of $\mathrm{CD}$.

CDI epidemiology. According to National Institute of Public Health - NIH data, 11592 cases of CD infection have been reported in Poland in 2018 (morbidity rate 30.2 per 100000 population) out of which 10084 $(87 \%)$ required hospital admission (4). The numbers are still increasing. In 2013, when CD infection surveillance and reporting were initiated, 4738 cases of CDI have been registered (4). However, these statistics are still believed to underestimate the true number of CD cases. Recurrence rate is approximately $20 \%$ and relapses occur most often at 3-21 days to 4-8 weeks after end of treatment (Table I). In half of the cases they are caused by the same CD strain. Elderly patients and immunosuppressed individuals are at particularly high risk of CDI recurrence. Detailed data on recurrence risk factors are presented in the treatment section.

Approximately $30 \%$ of all CDI cases are classified as healthcare-associated. However, in a proportion of patients' community-associated $C$. difficile infection

\section{WPROWADZENIE}

Definicja CDI. Objawowe zakażenie Clostridioides (Clostridium) difficile (CDI-Clostridioides difficile infection) jest ostrą choroba zapalną przewodu pokarmowego, manifestującą się co najmniej trzema nieuformowanymi stolcami w ciągu 24 godzin (1).

Etiologia CDI. Clostridium difficlile (CD) jest bakterią beztlenową Gram-dodatnią, wytwarzającą zarodniki (spory) oraz silne egzotoksyny (1). Dotychczasowa jej nazwa (Clostridium difficile) została zmieniona w 2016 roku na Clostridioides difficile, ze względu na przeniesienie jej do nowego rodzaju Clostridioides (2). Nadal dopuszczalne jest stosowanie obydwu nazw (3).

Bakterie Clostridium - szczepy nietoksynotwórcze mogą bytować w przewodzie pokarmowym noworodków oraz osób w wieku podeszłym. Bakterie Clostridioides nie stanowią flory fizjologicznej osób zdrowych, a ich wzrost w świetle jelita jest silnie thumiony przez prawidłową florę jelitową. Stosowanie leków zmieniających skład fizjologicznej flory jelitowej i redukujących liczbę bakterii prawidłowo występujących w jelicie grubym, sprzyja gwałtownemu wzrostowi CD.

Epidemiologia CDI. W 2013 roku, pierwszym roku, gdy zaczęto rejestrować przypadki zakażeń jelitowych CD, odnotowano 4738 przypadków CDI (4). W kolejnych latach ich liczba wzrastała. Zgodnie z danymi Narodowego Instytutu Zdrowia Publicznego - PZH, w 2018 roku zarejestrowano w Polsce 11592 przypadki zakażeń jelitowych wywołanych przez CD (zapadalność 30,2/100 tys.), z czego 10084 (87\%) wymagało hospitalizacji (4). Nie można jednak wykluczyć, że przedstawione meldunki nie oddają rzeczywistej skali problemu. Nawroty choroby występują u ok. $20 \%$ chorych po 3-21 dni do 4-8 tygodni od zakończenia leczenia (Tab. I). W połowie przypadków są one spowodowane przez ten sam szczep $C$. difficile. Nawroty CDI występują głownie u osób starszych z upośledzoną odpornością. Szczegółowe dane dotyczące czynników ryzyka nawrotów, przedstawiono w rozdziale na temat leczenia. 
Table I. CD recurrence rate

\begin{tabular}{|l|l|}
\hline $\begin{array}{l}\text { Recurrence } \\
\text { rate: }\end{array}$ & $\begin{array}{l}\bullet \text { After first episode: } 20 \% \\
\end{array}$ \\
& $\bullet$ After first recurrence: $45 \%$ \\
& $\bullet$ After second and further recurrence: $65 \%$ \\
\hline
\end{tabular}

(CA-CDI) can be diagnosed. It includes patients who do not belong to any of the recognized risk groups: young, with no history of antibiotic therapy or no history of contact with healthcare environment (Table II).
Tabela 1. Częstość nawrotów zakażenia CD

\begin{tabular}{|l|l|}
\hline Częstość & $\bullet 20 \%$ po pierwszym epizodzie \\
nawrotów & $\begin{array}{l}\bullet 45 \% \text { po pierwszym nawrocie } \\
\bullet 65 \% \text { po drugim i następnym epizodzie }\end{array}$ \\
\hline
\end{tabular}

Około 30\% CDI związanych jest z kontaktem ze środowiskiem szpitalnym. U części chorych występują zakażenia pozaszpitalne CA-CDI (community associated $-C D I$ ). Wśród nich są osoby spoza grup ryzyka: młode, nieleczone antybiotykami, bez kontaktu z ochroną zdrowia (Tab. II).

Table II. Hypotheses for the possible sources of community-associated CD strains

Tabela II. Hipotezy dotyczące źródła szczepów pozaszpitalnych

\begin{tabular}{|c|c|}
\hline \multicolumn{2}{|c|}{ Possible sources of community-associated CD straing } \\
\hline $\begin{array}{l}\text { 1. Widespread presence of } C \text {. difficile spores } \\
\text { in the environment }\end{array}$ & - soil, water \\
\hline 2. Contaminated alimentary products & $\begin{array}{l}\text { - pork, beef, poultry etc. } \\
\text { i. particularly vacuum packing } \\
\text { ii. C. difficile spores have been found in refrigerated meat in } \\
\text { cold rooms all over the world }\end{array}$ \\
\hline 3. Zoonotic infection & $\begin{array}{l}\text { Domestic animals (dogs, cats, horses etc.) can get infected with } \\
\text { C. difficile and excrete spores to the environment during diarrhea }\end{array}$ \\
\hline
\end{tabular}

\begin{tabular}{|c|c|}
\hline \multicolumn{2}{|l|}{ Możliwe źródła szczepów pozaszpitalnych } \\
\hline $\begin{array}{l}\text { 1. powszechna obecność spor } C \text {. difficile } \\
\text { w środowisku zewnętrznym }\end{array}$ & - gleba, woda \\
\hline 2. skażone produkty spożywcze & $\begin{array}{l}\text { - wieprzowina, wołowina, mięso kurczaków itd. } \\
\text { i. zwłaszcza pakowane próżniowo } \\
\text { ii. w chłodniach w różnych częściach świata w przechowy- } \\
\text { wanym mięsie znaleziono spory C. difficile }\end{array}$ \\
\hline 3. zakażenia odzwierzęce & $\begin{array}{l}\text { - zwierzęta domowe (psy, koty, konie itd.) mogą być zakażone } \\
\text { C. diffcile i podczas biegunki wydalać spory do środowiska }\end{array}$ \\
\hline
\end{tabular}

Spread of $C$. difficile infection occurs through spores, which are widely present around an infected patient as well as in the environment (Table III).

Table III. Characteristics of $C$. difficile spores

\begin{tabular}{|c|c|}
\hline & $\begin{array}{l}\text { Spores are the factor responsible for: } \\
\text { - easy spread of } C \text {. difficile in the hospital envi- } \\
\text { ronment, } \\
\text { - recurrence of antibiotic-associated diarrhea }\end{array}$ \\
\hline & $\begin{array}{l}\text { Sporulation process } \\
\text { - Environmental signals that initiate the process } \\
\text { remain unknown (RNA polymerase sigma factor) } \\
\text { - Lasts for approximately } 12 \text { hours }\end{array}$ \\
\hline & $\begin{array}{l}\text { Spores are resistant to environmental conditions } \\
\text { - dehydration } \\
\text { - extreme temperatures } \\
\text { - chemical products } \\
\text { - oxidative stress } \\
\text { - } \text { alcohol-containing hand sanitizers } \\
\end{array}$ \\
\hline
\end{tabular}

Czynnikiem odpowiedzialnym za rozprzestrzenianie się zakażeń $C$. difficile są spory, obecne w otoczeniu osoby chorej oraz w środowisku zewnętrznym (Tab. III).

Tabela III. Charakterystyka spor $C$. difficile

1. Spory są czynnikiem odpowiadającym za:

- szybkie rozprzestrzenianie się $C$. difficile w środowisku szpitalnym

- nawroty biegunek poantybiotykowych

2. Proces sporulacji

- nieznane są sygnały środowiskowe inicjujące proces (czynnik sigma polimerazy RNA ?)

- trwa około 12 godz.

3. Spory są oporne na warunki środowiskowe

- wysuszenie

- skrajne temperatury

- środki chemiczne

- stres tlenowy

- alkoholowe środki dezynfekcyjne do rąk 
Factors predisposing to CDI occurrence. Most cases of CDI are healthcare-associated, and the main factor for the development of the infection is hospitalization. It is estimated that approximately $82 \%$ of patients with CDI have been hospitalized within the last 12 weeks. It also applies to individuals who otherwise do not belong to any of the recognized risk groups, e.g. healthy women in perinatal period (5-10).

Another important determinant of CDI occurrence is the exposure to antibiotics within the last 12 weeks. Majority of patients (64\%) declare the use of antibiotics in the last 12 weeks prior to the first episode of CDI. The risk is particularly high within first 4 weeks of antibiotherapy and further increases with multiple drug use (11-12).

Use of any antibiotic can potentially lead to development of CDI. However, there are several antibiotic classes that carry a higher risk than others: third- and fourth generation cephalosporines, fluoroquinolones, carbapenems and clindamycin (13-16) (Table IV). The risk of CDI occurrence is individual and depends on local CD strains resistance to antibiotics (15).
Czynniki predysponujące do wystąpienia CDI. Większość przypadków CDI jest związana z opieką medyczną, głównie hospitalizacją. Szacuje się, że $82 \%$ chorych z rozpoznaniem CDI przebyło hospitalizację w ciągu ostatnich 12 tygodni. Dotyczy to także osób nieobciążonych innymi czynnikami ryzyka, czego przykładem są zdrowe kobiety w okresie okołoporodowym (5-10).

Drugi ważny czynnik rozwoju CDI to antybiotykoterapia w ciągu ostatnich 12 tygodni. Większość chorych (64\%) relacjonuje stosowanie antybiotyków do 12 tygodni przed pierwszym incydentem CDI. Ryzyko to jest szczególnie wysokie w pierwszych 4 tygodniach po antybiotykoterapii i rośnie przy zastosowaniu kilku antybiotyków $(11,12)$. Potencjalnie, zastosowanie każdego antybiotyku może spowodować wystąpienie CDI. Do klas o szczególnym wpływie na rozwój CDI należą jednak: cefalosporyny III i IV generacji, fluorochinolony, karbapenemy i klindamycyna (13-16) (Tab. IV). Ryzyko rozwoju CDI po zastosowaniu poszczególnych antybiotyków zależy od oporności na antybiotyki szczepów CD występujących lokalnie (15).

Table IV. Antibiotic classes and risk for $C$. difficile infection

Tabela IV. Ryzyko wywołania infekcji $C$. difficile przez antybiotyki

\begin{tabular}{|l|l|l|}
\hline \multicolumn{1}{|c|}{ HIGH } & \multicolumn{1}{|c|}{ MODERATE } & \multicolumn{1}{c|}{ LOW } \\
\hline Clindamycin & Sulfonamides & Rifampicin \\
Ampicillin & Macrolides & Chloramphenicol \\
Amoxycillin & Carbapenems & Aminoglycosides \\
Cephalosporines & Other penicillins & Tetracyclin \\
Fluoroquinolones & & \\
\hline
\end{tabular}

Out of patients who developed CDI despite no history of antibiotic exposure, $31 \%$ was treated with proton-pump inhibitors (PPI) (17), which, together with H2-blockers, are an important factor contributing to CDI occurrence. Another treatment-related risk group for CDI includes patients receiving chemotherapy, particularly those who are neutropenic (18-22). Gastrointestinal surgical procedures and alimentation through stomach probe also increase significantly the risk of CDI (16,23),

Other risk factors for CDI include advanced age, chronic comorbidities: renal failure, liver failure, chronic inflammatory bowel diseases (particularly ulcerative colitis), neoplasms, HIV infection, diseases leading to cachexia and hypoalbuminemia, as well as vitamin D3 deficiency (24-27).

Solid organs and bone marrow transplant recipients are at over 5 times higher risk of CDI development, as well as at high risk for recurrence, severe disease and death $(28,29)$ (Table V).
Spośród tych, którzy nie stosowali antybiotyków a rozwinęli CDI, aż 31\% stosowała inhibitory pompy protonowej (IPP) (17), które uważa się obecnie, obok blokerów H2, za istotny czynnik ryzyka rozwoju CDI. $\mathrm{W}$ grupie ryzyka związanego z zastosowanym leczeniem są także chorzy podlegający chemioterapii nowotworów, szczególnie w fazie neutropenii (18-22). Szczególnym ryzykiem rozwoju CDI obarczeni są pacjenci poddani zabiegom chirurgicznym w obrębie przewodu pokarmowego, a także żywieni przez sondę $(16,23)$.

Wśród innych czynników ryzyka CDI wymienia się: podeszły wiek, przewlekłe choroby współistniejące takie jak niewydolność nerek, niewydolność wątroby, przewlekłe choroby zapalne jelit - szczególnie wrzodziejące zapalenie jelita grubego, nowotwory, zakażenie HIV, choroby przebiegające $\mathrm{z}$ wyniszczeniem i hipoalbuminemią oraz niedobór witaminy D3 (24-27).

Szczególną grupę stanowią biorcy narządów oraz szpiku. W tej grupie ryzyko zachorowania na CDI jest 5-krotnie wyższe, a ponadto występuje wysokie ryzyko nawrotu biegunki oraz ciężkiego przebiegu zakażenia CDI i zgonu $(28,29)$ (Tab. V). 
Table V. Risk factors for $C$. difficile infection

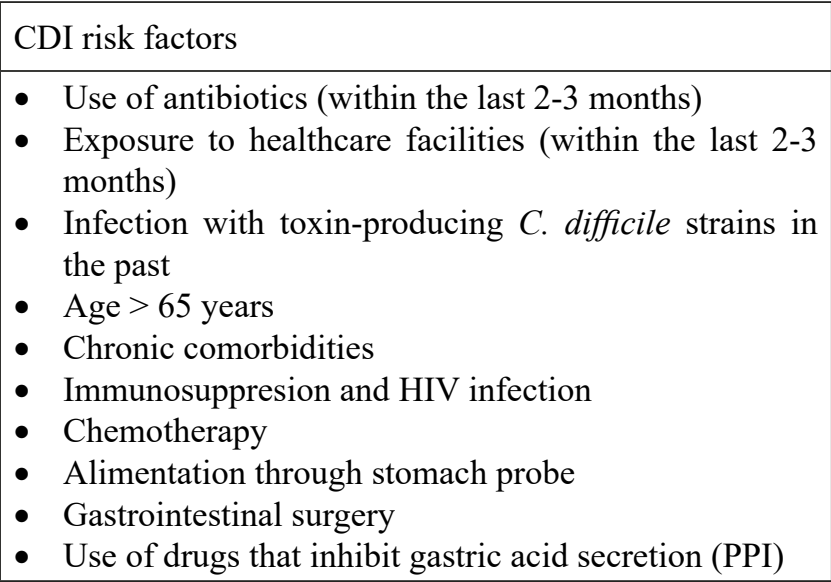

Clinical Presentation. CDI clinical presentation depends on CD type and on the patient's health status including presence of comorbidities at the time of infection. Common CDI symptoms are listed in Table VI.

Table VI. Common symptoms of $C$. difficile infection

\begin{tabular}{|l|}
\hline Clinical symptoms of CDI \\
\hline - Loss of appetite \\
Diarrhea \\
$\quad$ watery diarrhea ( $>3$ loose stools per 24 hours) of \\
$\quad$ varying severity \\
$\quad$ fulminant (often lethal) pseudomembranous \\
colitis \\
- Fever \\
- Abdominal pain or discomfort \\
- Extraintestinal manifestations \\
$\quad$ arthritis \\
\hline
\end{tabular}

Severity of $C$. difficile disease can be influenced by numerous factors. Clinical manifestations of CDI are presented in Table VII.

Table VII. CDI clinical manifestations

\begin{tabular}{|c|}
\hline CDI clinical manifestations \\
\hline $\begin{array}{l}\text { - Asymptomatous carriers = colonisation } \\
\text { - Mild or moderate diarrhea } \\
\text { - Pseudomembranous colitis }\end{array}$ \\
\hline
\end{tabular}

The most severe disease is associated with ribotype 027, or NAP1 (North American Pulsed Field Type 1), infection. Hyperepidemic NAP1/BI/027 strain has stronger spore formation and toxin production abilities. Increased prevalence of NAP1/BI/027 infection has been observed lately. NAP1 strain exhibits resistance to fluoroquinolones (which has been increasing over recent years) and may cause severe CDI associated with high risk of death (13).
Tabela V. Czynniki ryzyka zakażenia C. difficile.

Czynniki ryzyka CDI

- Antybiotykoterapia (w ciągu ostatnich 2-3 miesięcy)

- Kontakt z placówkami ochrony zdrowia (w ciągu ostatnich 2-3 miesięcy)

- Przebyta infekcja toksynotwórczym szczepem $C$. difficile

- Wiek $\geq 65$ rż

- Przewlekłe choroby

- Immunosupresja oraz zakażenie HIV

- Chemioterapia

- Żywienie dojelitowe

- Operacja przewodu pokarmowego

- Stosowanie leków blokujących wydzielanie kwasu solnego (szczególnie IPP)

Objawy kliniczne CDI. Przebieg kliniczny CDI zależy od typu CD oraz stanu ogólnego chorego i chorób współistniejących w chwili zakażenia. Typowe objawy CDI zawarte są w tabeli VI.

Tabela VI. Objawy kliniczne zakażenia $C$. difficile

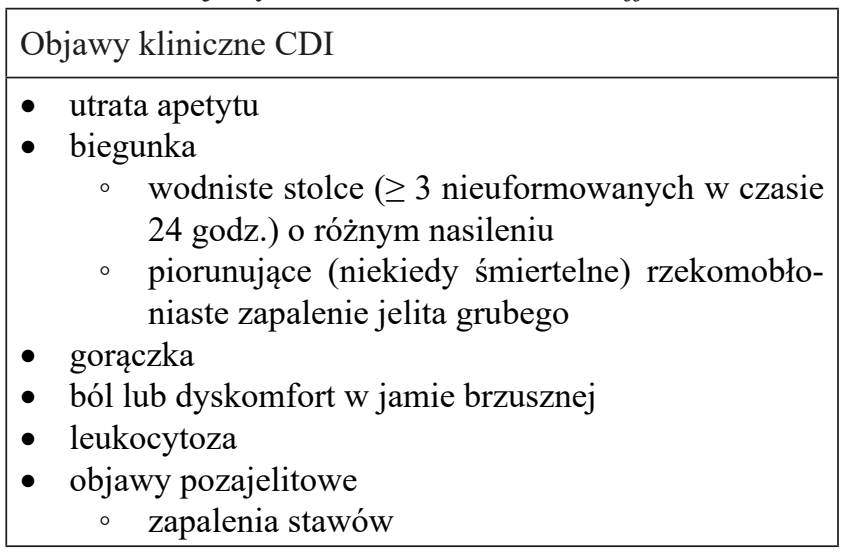

Ciężkość przebiegu zakażenia $C$. difficile jest uwarunkowana wieloma czynnikami. Postacie kliniczne CDI przedstawiono w tabeli VII.

Tabela VII. Postacie kliniczne zakażenia $C$. difficile

\begin{tabular}{|c|}
\hline Postacie kliniczne CDI \\
\hline $\begin{array}{l}\text { - Bezobjawowi nosiciele = kolonizacja } \\
\text { - } \text { Lagodna lub umiarkowana biegunka } \\
\text { - Rzekomobłoniaste zapalenie jelita grubego }\end{array}$ \\
\hline
\end{tabular}

Najcięższy przebieg wiąże się z zakażeniem rybotypem 027, znanym także jako NAP1 (North American Pulsed Field Type 1). Wykazano, że hiperepidemiczny szczep NAP1/BI/027 ma dużą zdolność do sporulacji oraz wysoką toksynotwórczość. W ostatnich latach obserwuje się zwiększoną częstość występowania zakażeń tym szczepem. Szczep NAP1 charakteryzuje się dużą opornością na fluorochinolony (narastającą w ostatnich latach) oraz wywoływaniem CDI o cięż- 
CD disease severity can be determined based on clinical data (medical history, physical examination and laboratory testing results), the need for intensive care unit (ICU) admission and the need for colectomy (1).

Mild, moderate, and severe CDI can be distinguished (1). The clinical classification incorporates the following criteria (Table VIII).

Apart from leukocytosis and serum creatinine, the prognosis and death risk in CDI depend on several other factors, including age, body temperature, exposure to systemic antibiotics and albumin concentration (Table IX).

Table VIII. Classification of $C$. difficile disease severity Tabela VIII. Klasyfikacja ciężkości przebiegu klinicznego zakażenia $C$. difficile

\begin{tabular}{|l|l|}
\hline Disease severity & Criteria \\
\hline Mild/moderate & $\bullet \quad \mathrm{WBC}<15000 / \mathrm{mL}$ \\
& $\bullet \quad$ Serum creatinine $<1,5 \mathrm{mg} / \mathrm{dL}$ \\
\hline Severe & $\bullet \quad \mathrm{WBC}>15000 / \mathrm{mL}$ \\
& $\bullet \quad$ Serum creatinine $>1,5 \mathrm{mg} / \mathrm{dL}$ \\
\hline Fulminant & - WBC $>15000 / \mathrm{mL}$ \\
& $\bullet \quad$ Serum creatinine $>1,5 \mathrm{mg} / \mathrm{dL}$ \\
& $\bullet \quad$ Arterial hypotension \\
\hline
\end{tabular}

Aforementioned parameters were included in ATLAS classification (ATLAS score) - Table X (30). Score of 8 is associated with mortality rate as high as $56 \%(31)$. kim przebiegu, a zakażenie nim jest obarczone większym ryzykiem zgonu (13).

Ciężkość przebiegu CDI, określa się na podstawie danych klinicznych (badanie podmiotowe, przedmiotowe, wyników badań laboratoryjnych), konieczności pobytu w Oddziale Intensywnej Terapii (OIT) oraz konieczności wykonania kolektomii (1). Wyróżnia się lekki, umiarkowany oraz ciężki przebieg CDI (1). Klasyfikacja kliniczna oparta jest na poniższych kryteriach (Tab. VIII).

Rokowanie i ryzyko zgonu w przebiegu CDI są także związane (poza liczbą leukocytów i stężeniem kreatyniny w surowicy) z wiekiem, temperaturą ciała, stosowaniem systemowej antybiotykoterapii oraz stężeniem albumin w surowicy (Tab. IX).

Table IX. Risk factors for severe CDI disease

Tabela IX. Czynniki ryzyka ciężkiego przebiegu zakażenia C. difficile

\begin{tabular}{|ll|}
\hline Risk factors for severe CDI disease \\
\hline - & age $>70$ years \\
- & leukocytosis $>20000 / \mathrm{mm}^{3}$ \\
- & serum creatinine $>2 \mathrm{mg} / \mathrm{dl}$ \\
- & intestinal inflammation \\
- & surgery within last 30 days \\
\hline
\end{tabular}

Table X. Risk prediction for mortality in CDI - ATLAS score (30)

Tabela X. Skala oceny ryzyka zgonu w przebiegu CDI - ATLAS score (30)

\begin{tabular}{|c|c|c|c|}
\hline Parameter & 0 points & 1 point & 2 points \\
\hline Age $($ years $)$ & $<60$ & $60-79$ & $\geq 80$ \\
\hline Temperature $\left({ }^{\circ} \mathrm{C}\right)$ & $<37,5$ & $37,6-38,5$ & $\geq 38,6$ \\
\hline Leukocytosis $($ cells/ $\mu \mathrm{L})$ & $<16,000$ & $16,000-25,000$ & $>25,000$ \\
\hline Serum albumin $(\mathrm{g} / \mathrm{L})$ & $>35$ & $26-35$ & $<25$ \\
\hline Exposure to systemic antibiotics $>1$ day & no & - & yes \\
\hline Serum creatinine $(\mu \mathrm{mol} / \mathrm{L})$ & $\leq 120$ & $121-179$ & $\geq 180$ \\
\hline
\end{tabular}

CDI complications. One of the life-threatening complications of CDI is toxic megacolon (Table XI). It occurs in $4 \%$ of patients with CDI and its prevalence has been increasing over recent years (32). Treatment should involve the antibiotics recommended to use in severe/fulminant CDI cases, or surgery (i.e. colectomy). The colectomy rates have been reported to vary between $0.3-6.2 \%$ in different patient populations (33).
Powikłania CDI. Ciężkim powikłaniem CDI jest toksyczne rozdęcie okrężnicy (TRO). Częstość występowania tego powikłania wynosi ok $4 \%$ i zgodnie $\mathrm{z}$ obserwacjami licznych autorów rośnie w ostatnich latach (32). TRO wymaga leczenia zachowawczego zgodnie ze schematem stosowanym w przebiegu ciężkim i piorunującym lub leczenia chirurgicznego polegającego na kolektomii. Konieczność wykonania kolektomii 
Cases of gastrointestinal tract candidiasis caused by Candida spp have been observed during CDI treatment or within 120 days of follow up $(0.8 \%$ of cases). It is promoted mostly by metronidazole treatment (34).

CDI is a recurrent disease. The estimated recurrence rate of $\mathrm{CDI}$ is $10 \%$ to $30 \%(33,35,36)$, however, it further increases after each relapse. Moreover, a significant increase in overall mortality due to CDI has been observed in recent years. While in 2000 it did not exceed $2 \%$, at present the morality rate in Intensive Care Units varies between $4.5 \%$ up to $16.7 \%$ during epidemic outbreak of NAP1/ribotype 027 (37).

The risk of death in patients with CDI is particularly high during disease recurrence. It has been estimated that the rate of deaths within 180 days of follow-up after CDI in patients with CDI relapse is even 33\% higher than in patients with no history of recurrent infection (38).

\section{DIAGNOSTICS REKOMENDATIONS}

1. Appearance of at least 3 loose stools in a 24-hour period in patients from risk groups for CDI is an indication to perform the testing $(39,40)$.

2. The golden standard for CDI diagnostics is the examination of the watery stool.

Unformed stool is the only acceptable specimen (i.e. stool conforms to shape of the container). It is not recommended to test formed stool specimens or to perform rectal swabs (Table XII).

3. Diagnosis of CDI should be based on the detection of toxins or antigens of toxin-producing $\mathrm{CD}$ in stool specimen (Table XIII).

Diagnostic algorithm for the detection of CDI involves the detection of glutamate dehydrogenase (GDH) and A and/or B toxins. The presence of GDH with negative results for $\mathrm{A}$ and/or B toxins is an indication to perform a nucleic acid amplification test (NAAT) $(40,41)$. This protocol of CDI detection seems to bring more specific and more sensitive results than the isolated assessment of toxin-producing $\mathrm{CD}$ genes with NAAT testing. Such complete diagnostic panel (GDH+ A/B toxins), instead of isolated NAAT testing, should always be performed (1) (Table XIII). It has to be remembered that CD $\mathrm{A}$ and $\mathrm{B}$ toxins are very unstable, degrade at room temperature and might be undetectable within two hours after collection of a stool specimen. Biological markers (e.g. lactoferrin, calprotectin) are not recommended in CDI.

Presence of GDH with absence of A/B toxins, positive result of NAAT testing and presence of raportowano z częstością od $0,3 \%$ do $6,2 \%$ w różnych grupach pacjentów (33). W przebiegu leczenia CDI lub w ciągu 120 dni po terapii, obserwowano także przypadki grzybicy przewodu pokarmowego o etiologii Candida spp (0,8\% przypadków). Wystąpieniu grzybicy sprzyja głównie leczenie metronidazolem (34).

CDI jest chorobą nawrotową. Częstość nawrotów szacuje się na $10-30 \%(33,35,36)$ jednak należy odnotować, że z każdym nawrotem ryzyko wystąpienia kolejnych nawrotów rośnie. W ostatnich latach obserwuje się rosnący odsetek zgonów w przebiegu CDI. O ile do 2000 roku notowano około $2 \%$ zgonów w przebiegu tej choroby, o tyle obecnie ryzyko zgonu w OIT wynosi od $4,5 \%$ do $16,7 \%$ chorych - odpowiednio w czasie endemii lub epidemii CDI wśród chorych zakażonych szczepem epidemicznym NAP1 o rybotypie 027 (37). Wśród chorych leczonych z powodu CDI ryzyko zgonu jest szczególnie wysokie podczas nawrotu choroby. Oszacowano, że ryzyko zgonu w ciągu 180 dni po przebyciu CDI u chorych z nawrotami biegunki jest nawet o $33 \%$ wyższe niż u chorych bez nawrotu choroby (38).

\section{REKOMENDACJE DOTYCZĄCE DIAGNOSTYKI CDI}

1. Pojawienie się co najmniej 3 nieuformowanych stolców w ciągu 24 godzin u osoby z grupy ryzyka CDI jest wskazaniem do wykonania badań w kierunku tego zakażenia $(39,40)$.

2. Podstawą diagnostyki etiologicznej CDI jest badanie stolca biegunkowego.

Do badania należy pobrać stolec płynny tzn. przyjmujący kształt naczynia, do którego jest pobierany. $\mathrm{W}$ przeciwnym wypadku wyniki badania obecności toksyny CD mogą być fałszywie negatywne. Nie należy pobierać stolca uformowanego ani wykonywać wymazów z odbytu celem rozpoznania CDI, gdyż taki materiał nie nadaje się do oceny (Tab. XII).

3. Podstawę rozpoznania stanowi wykazanie obecności toksyny lub genów toksynotwórczych $\mathrm{CD}$ w kale (Tab. XIII).

Algorytm diagnostyczny składa się z oceny obecności w kale dehydrogenazy glutaminianowej (GDH) oraz toksyn $\mathrm{A}$ i/lub $\mathrm{B} C$. difficile. W przypadku dodatniego wyniku GDH i braku toksyn A i/lub B w kale należy wykonać badanie amplifikacji kwasów nukleinowych (NAAT - Nucleic acid amplification tests) (Tab. XIII) $(40,41)$.

Taki sposób diagnozowania CDI wydaje się bardziej czuły i swoisty niż ocena samej obecności genów toksynotwórczych CD metodą NAAT. Należy więc dążyć do wykonania pełnego panelu diagnostycznego (GDH + toksyny A/B), a nie tylko samego NAAT (1), tabela XIII. Należy pamiętać, że toksyny A i B są bardzo niestabilne, degradowane w temperaturze 
clinical symptoms as well as risk factors for CDI is highly suggestive of CD and should be considered the reason for treatment initiation.

Table XI. Possible complications in severe CDI

\begin{tabular}{|l|}
\hline CDI complications \\
\hline - dehydration \\
- dyselectrolytemia \\
- toxic megalbuminemia \\
- bowel perforation \\
- sepsis \\
- death \\
\hline
\end{tabular}

Table XII. Recommended diagnostic strategy for CDI detection CDI diagnostic strategy

- The only acceptable specimen is the watery (i.e. unformed) stool

- Testing should not be performed in asymptomatic patients

- No screening tests are recommended

Table XIII. Recommended diagnostic algorithm for CDI

\begin{tabular}{|l|}
\hline Basis of CDI diagnosis \\
\hline - Golden standard: stool culture with detection of toxin- \\
producing CD strain \\
- GDH + toxins \\
- GDH + toxins confirmed with NAAT testing \\
\hline
\end{tabular}

4. Stool culture is not recommended in clinical practice due to its low specificity.

The culture allows for the detection of other than vegetative $C D$ cells and positive results can be difficult to interpret. Specificity, sensitivity and diagnostic properties of each test used for CDI detection are listed in Tables XIV and XV (1). pokojowej i są niewykrywalne po 2 godzinach od pobrania materiału. Nie zaleca się badania markerów biologicznych (np. laktoferyny, kalprotektyny) w zakażeniu CD.

Praktyka kliniczna wskazuje, że w przypadku braku obecności toksyny i pozytywnego wyniku NAAT, z jednoczesną obecnością objawów klinicznych i czynników ryzyka CDI, należy podejrzewać zakażenie CD i włączyć leczenie opisane poniżej.

Tabela XI. Powikłania CDI o ciężkim przebiegu

\begin{tabular}{|c|}
\hline Powikłania CDI \\
\hline $\begin{array}{l}\text { - } \text { odwodnienie } \\
\text { - zaburzenia elektrolitowe } \\
\text { - } \text { hipoalbuminemia } \\
\text { - } \text { toksyczne rozdęcie okrężnicy (megacolon toxicum) } \\
\text { - perforacja jelita grubego } \\
\text { - posocznica } \\
\text { - zespół niewydolności wielonarządowej } \\
\text { - zgon }\end{array}$ \\
\hline
\end{tabular}

Tabela XII. Rekomendowana strategia diagnostyki CDI

Strategia diagnostyki CDI

- Badanie powinno być wykonane tylko ze stolca biegunkowego (nieuformowanego)

- Badanie nie powinno być wykonywane u osób bezobjawowych

- Nie zaleca się badań przesiewowych

Tabela XIII. Rekomendowany algorytm diagnostyczny CDI

Podstawa rozpoznania CDI

- Złoty standard: posiew kału z wykryciem szczepu toksynotwórczego

- $\mathrm{GDH}+$ toksyny

- $\mathrm{GDH}+$ toksyny potwierdzone badaniem NAAT

- NAAT + toksyny

4. W warunkach praktyki klinicznej nie zaleca się diagnostycznej hodowli CD, ze względu na bardzo małą swoistość jej wyników.

Hodowla ujawnia bowiem nie tylko wegetatywne komórki $\mathrm{CD}$, ale także spory i wyniki pozytywne mogą być trudne do interpretacji. W tabeli XIV i XV przedstawiono czułość, swoistość oraz znaczenie diagnostyczne poszczególnych testów stosowanych w rozpoznaniu CDI (1). 
Table XIV. Sensitivity, specificity and diagnostic properties of laboratory tests used for CDI detection (1)

Tabela XIV. Czułość, swoistość oraz znaczenie diagnostyczne poszczególnych testów stosowanych w rozpoznaniu CDI (1)

\begin{tabular}{|l|c|c|c|}
\hline \multicolumn{1}{|c|}{ Test } & Sensitivity & Specificity & Target: \\
\hline Culture & High & Low & Vegetative C. difficile cells and spores \\
\hline $\begin{array}{l}\text { Nucleic acid amplification tests } \\
\text { (NAAT) }\end{array}$ & High & Low/moderate & $\begin{array}{c}\text { C. difficile genetic material (toxin } \\
\text { genes) }\end{array}$ \\
\hline Glutamate dehydrogenase (GDH) & High & Low & C. difficile antigen \\
\hline Cell-based toxin-neutralization assays & High & High & Free toxin \\
\hline $\begin{array}{l}\text { Immunoenzymatic assay for the } \\
\text { detection of A/B toxin }\end{array}$ & Low & Moderate & Free toxin \\
\hline
\end{tabular}

Table XV. CDI diagnostics

Tabela XV. Diagnostyka CDI

\begin{tabular}{|c|c|c|c|}
\hline \multicolumn{2}{|r|}{ Test } & Advantages & Disadvantages \\
\hline \multirow[t]{2}{*}{ Toxin detection } & Enzyme immunoassay (EIA) & 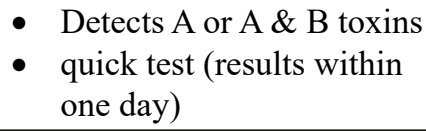 & Sensitivity $63-94 \%$ \\
\hline & $\begin{array}{l}\text { Cell-based cytotoxicity } \\
\text { assays }\end{array}$ & $\begin{array}{l}\text { Sensitivity and specificity: } \\
67-100 \%\end{array}$ & $\begin{array}{ll}\text { - } & \text { Detects B toxin } \\
\text { - } & \text { Requires laboratory } \\
& \text { equipment } \\
\text { - } & \text { High costs } \\
\text { - } & \text { Results after } 24-48 \text { hours }\end{array}$ \\
\hline \multirow[t]{3}{*}{ Bacteria detection } & Glutamate dehydrogenase & $\begin{array}{l}\text { Fast, sensitive, can be used in } \\
\text { screening }\end{array}$ & $\begin{array}{l}\text { - Low specificity } \\
\text { - } \text { Requires further } \\
\text { verification }\end{array}$ \\
\hline & PCR & $\begin{array}{l}\text { Fast, sensitive, allows for } \\
\text { toxin genes detection }\end{array}$ & $\begin{array}{ll}\text { - } & \text { High costs } \\
\text { - } & \text { Requires laboratory } \\
\text { equipment }\end{array}$ \\
\hline & Stool culture & The most sensitive method & $\begin{array}{l}\text { - Does not detect toxins } \\
\text { - } \text { Results after 48-96 hours }\end{array}$ \\
\hline
\end{tabular}

\section{TREATMENT RECOMMENDATIONS}

\section{Treatment of the first episode}

1. Treatment of the first episode of CDI should primarily involve the soonest possible withdrawal of previous antibiotics.

Use of the antibiotics that do not suppress $\mathrm{CD}$ growth has been proven to worsen response to treatment and increases recurrence rate $(37,42)$. Safety of antimotility agents (e.g. loperamide) has not been determined; however, they are not recommended in patients at high risk of toxic megacolon $(43,44)$.

2. CDI diagnostics should not delay treatment.

Clinical suspicion of CDI in patients from risk groups, as well as in individuals with fulminant disease, are indications to start empirical therapy, especially when time to confirmation of the infection is anticipated to be prolonged.

3. The choice of treatment regimen depends on clinical severity of the disease (Table XVI).

\section{REKOMENDACJE DOTYCZĄCE LECZENIA CDI}

\section{Leczenie pierwszego incydentu CDI}

1. Rozpoczynając leczenie CDI należy w pierwszej kolejności zakończyć, tak szybko jak to możliwe, dotychczasową antybiotykoterapię.

Wykazano, że stosowanie antybiotyków niehamujących wzrostu CD, pogarsza odpowiedź na leczenie i zwiększa ryzyko nawrotów $(37,42)$. Nie jest ustalone bezpieczeństwo stosowania leków hamujących perystaltykę (np. loperamid); nie zaleca się ich stosowania u pacjentów z wysokim ryzykiem rozwoju toksycznego rozdęcia okrężnicy $(43,44)$.

2. Diagnostyka CDI nie może opóźnić wdrożenia leczenia. Kliniczne podejrzenie CDI u chorych z grup ryzyka oraz pacjentów z piorunującym przebiegiem jest wskazaniem do rozpoczęcia terapii empirycznej w przypadku, gdy oczekuje się długiego czasu potwierdzenia zakażenia.

3. Wybór schematu leczenia zależy od przebiegu klinicznego choroby (Tab. XVI). 
Table XVI. Possible regimens for the treatment of the first CDI episode (1)

Tabela XVI. Zasady leczenia pierwszego incydentu CDI w zależności od przebiegu klinicznego (1)

\begin{tabular}{|c|c|c|c|}
\hline & Mild/moderate & Severe & Fulminant \\
\hline First-line treatment & $\begin{array}{c}\text { VAN 4x125 mg p.o. } \\
\text { for 10 days }\end{array}$ & $\begin{array}{c}\text { VAN 4x125 mg p.o. } \\
\text { for } 10 \text { days }\end{array}$ & $\begin{array}{c}\text { VAN 4x500 mg p.o. } / \text { p.r. } \\
\text { + Metronidazole 3x 500 mg i.v. }\end{array}$ \\
\hline Alternative treatment & $\begin{array}{c}\text { FDX 2x200 mg p.o. } \\
\text { for 10 days }\end{array}$ & $\begin{array}{c}\text { FDX 2x200 mg p.o. } \\
\text { for } 10 \text { days }\end{array}$ & $\begin{array}{c}\text { Subtotal colectomy or ileostomy with colonic } \\
\text { lavage }\end{array}$ \\
\hline
\end{tabular}

VAN - vancomycin; FDX - fidaxomycin; p.o. - per os; p.r .- per rectum

- Oral vancomycin is considered the first-line treatment. The recommended vancomycin dose is $125 \mathrm{mg}$ every 6 hours for 10 days $(45,46)$. Slow clinical improvement or partial resolution of the symptoms can justify prolonging the treatment up to 14 days (48).

- Alternatively, $200 \mathrm{mg}$ of fidaxomicin given every 12 hours for 10 days can be used for the treatment of the first CD episode. This is particularly recommended in patients who are at high risk of CDI recurrence, since in clinical trials fidaxomicin was proven to decrease the risk of relapse within 25 days after treatment compared to vancomycin $(47,48)$.

- Metronidazole is no longer recommended as a standard monotherapy of CDI. Given orally, it can be an alternative for patients who are at low risk of recurrence or severe CDI disease when other medications are not available. In such cases metronidazole can be given orally for 10 days (500 mg every 8 hours) (49).

- Fulminant CD disease is an indication to 500 mg of vancomycin every 6 hours given orally or through stomach probe. If intestinal obstruction occurs, addition of vancomycin enema (500 $\mathrm{mg}$ in $100 \mathrm{ml}$ of solution every 6 hours) can be considered. Combination of oral or rectal treatment with $500 \mathrm{mg}$ of metronidazole given intravenously every 8 hours is also recommended in case of ileus (50).

- Colon perforation is an indication to surgical treatment involving subtotal colectomy or ileostomy. Diverting loop ileostomy together with colonic lavage and vancomycin administration, is an alternative than can improve the outcomes (51). Possible regimens for the treatment of the first CDI episode are listed in Table XVI.
- Obecnie podstawą terapii jest wankomycyna stosowana $\mathrm{w}$ dawce $125 \mathrm{mg}$ doustnie $4 \mathrm{x}$ dziennie przez 10 dni $(45,46)$. W przypadku powolnej poprawy klinicznej lub niecałkowitego ustąpienia biegunki, leczenie można przedłużyć do 14 dni (48).

- W leczeniu pierwszego incydentu w miejsce wankomycyny można zastosować fidaksomycynę w dawce $200 \mathrm{mg}$ doustnie 2x dziennie przez 10 dni. Lek ten jest polecany głównie u chorych z dużym ryzykiem nawrotu CDI, gdyż jak wykazano (w badaniu klinicznym), zmniejszał istotnie ryzyko nawrotu w ciągu 25 dni w stosunku do wankomycyny $(47,48)$.

- Obecnie nie stosuje się rutynowo metronidazolu w monoterapii (w leczeniu) CDI. Dopuszcza się jego zastosowanie jedynie u pacjentów z niskim ryzykiem nawrotów i ciężkiego przebiegu CDI oraz w przypadku braku dostępności innych leków. W takich przypadkach metronidazol może być stosowany doustnie w dawce $500 \mathrm{mg} \mathrm{3x}$ dziennie przez 10 dni (49).

- Piorunujący przebieg CDI wymaga leczenia wankomycyną w dawce $500 \mathrm{mg} \mathrm{4x}$ dziennie podawaną doustnie lub przez sondę żołądkową. Jeśli dochodzi do niedrożności przewodu pokarmowego należy rozważyć połączenie leczenia doustnego z wlewkami doodbytniczymi wankomycyny $(500 \mathrm{mg} \mathrm{w}$ roztworze $100 \mathrm{ml}$ co 6 godzin). W przypadku niedrożności zaleca się także połączenie terapii doustnej lub doodbytniczej z dożylnym zastosowaniem metronidazolu w dawce $500 \mathrm{mg}$ co 8 godzin (50). Nierzadko pacjenci wymagają $\mathrm{w}$ tym okresie wprowadzenia żywienia pozajelitowego.

- W przypadku perforacji jelita konieczne jest leczenie chirugiczne obejmujące subtotalną kolektomię lub wyłonienie stomii jelitowej. Wykonanie stomii z pętlą zwrotną wraz z płukaniem okrężnicy, po której następuje podanie wankomycyny, jest alternatywnym podejściem, które może poprawiać wyniki leczenia (51). Schematy leczenia pierwszego incydentu CDI przedstawiono w tabeli XVI. 


\section{Treatment of CDI recurrence}

1. Recommended treatment approach is similar for the first and the subsequent recurrences.

Tendency to cause relapses and impossibility to modify disease risk factors both contribute to the fact that patients who are at high risk of relapse often experience not only one, but several CDI episodes. Recent years' experience suggests that treatment of the first relapse should be of similar intensity as that of the subsequent episodes. Risk factors for CDI recurrence include: advanced age, comorbidities, immunological exhaustion, PPI treatment continuation and exposure to antibiotics that are inactive against $\mathrm{CD}$ during treatment of the first CDI episode (e.g. the concurrent treatment of the respiratory tract or urinary tract infections) (1). The risk for recurrence after first CDI episode that was treated with vancomycin is estimated to be approximately $25 \%(47,48)$, and it significantly decreases if primary CDI episode was treated with fidaxomicin (47).

2. Vancomycin given orally (125 mg every 6 hours) for 10-14 days followed by vancomycin taper and pulse regimen (as presented in Table XVII) constitutes the first-line treatment in CDI recurrences (1).

\section{Leczenie nawrotu CDI}

1. Rekomenduje się te same metody leczenia zarówno dla nawrotu pierwszego, jak i kolejnych nawrotów. Nawrotowy charakter CDI oraz niemożność modyfikacji czynników ryzyka choroby sprawiają, że u chorych z wysokim ryzykiem nawrotu choroby należy oczekiwać nie jednego, ale licznych nawrotów choroby. Obserwacje ostatnich lat wskazują, że leczenie pierwszego nawrotu powinno zatem być tak samo intensywne, jak leczenie kolejnych nawrotów. Za czynniki ryzyka nawrotu CDI uważa się: podeszły wiek, choroby współistniejące, wyczerpanie immunologiczne, kontynuacja leczenia IPP oraz stosowanie antybiotyków nieaktywnych wobec CD w trakcie leczenia pierwszego incydentu CDI (np. konieczność leczenia zakażenia układu oddechowego lub moczowego) (1). Ryzyko nawrotu po leczeniu pierwszego epizodu CDI wankomycyną, szacuje się na 25\% (47,48). Ryzyko nawrotu szacuje się jako istotnie mniejsze, gdy w leczeniu pierwotnego incydentu CDI zastosowano fidaksomycynę (47).

2. Podstawą leczenia nawrotów CDI jest wankomycyna stosowana doustnie początkowo w dawce $4 \times 125$ mg przez 10-14 dni z następczym zastosowaniem terapii stożkowej redukcyjnej wankomycyną w stopniowo zmniejszanych dawkach - a następnie w dawkach malejących według schematu podanego w tabeli XVII (1).

Table XVII. Guidelines for treatment for the CDI recurrences (1)

Tabela XVII. Zasady leczenia nawrotów CDI (1)

\begin{tabular}{|c|l|c|}
\hline Regimen & \multicolumn{1}{|c|}{ Medications and procedures } & Treatment duration \\
\hline \multirow{3}{*}{ First-line treatment } & - VAN 125mg qid & $10-14$ days, \\
& $\begin{array}{l}\text { followed by } 125 \mathrm{mg} \text { bid } \\
\text { followed by } 125 \mathrm{mg} / \mathrm{d} \\
\text { followed by } 125 \mathrm{mg} \mathrm{q} 2-3 \text { days }\end{array}$ & 7 days, \\
& - VAN 125mg qid + FMT & $2-8$ weeks \\
\hline Alternative treatment I & FDX 200 mg bid + FMT to consider & $10-14$ days \\
\hline Alternative treatment II & FDT days \\
\hline
\end{tabular}

VAN - vancomycin p.o.; FDX - fidaxomicin p.o.; FMT - fecal microbiota transplantation; qid - four times per day; bid twice per day

- Rifaximin is not recommended for the continuation of the therapy since the evidence for its efficacy in preventing subsequent relapses is not sufficient $(1,52)$.

- The presented vancomycin regimen should be used in every patient who was previously treated with metronidazole.

- If first episode of CDI was treated with vancomycin, fidaxomicin (200 mg every 12 hours for 10 days) should be considered as an approach for the treatment of CDI relapse. Compared to vancomycin, fidaxomicin reduces
- Stosowanie kontynuacji terapii w postaci rifaksyminy nie przynosi oczekiwanych efektów w zapobieganiu kolejnym nawrotom i brak jest silnych dowodów przemawiających za jej stosowaniem $(1,52)$.

- Powyższy schemat leczenia wankomycyną należy zastosować zawsze, jeśli pierwszy incydent CDI był leczony metronidazolem. W przypadku leczenia nawrotu CDI po leczeniu wankomycyną pierwszego incydentu, należy rozważyć leczenie fidaxomycyną w dawce 2x $200 \mathrm{mg}$ przez $10 \mathrm{dni}$.

- Zastosowanie fidaksomycyny zmniejsza ryzyko 
the risk of subsequent relapses $(35,5 \%$ versus $19,7 \%$, respectively) (48).

3. Monoclonal antibodies against $C$. difficile toxins emerge as the new direction for the research and new therapeutic approach in CDI treatment and prevention of the recurrences.

First monoclonal antibody that binds to B toxin and was approved by FDA is bezlotoxumab. Results of P001 and P002 clinical trials confirmed the efficacy of this particle, especially in combination with another monoclonal antibody binding to A toxin (actoxumab), in the prevention of CDI relapse (53). Significantly lower recurrence rates were reported in patients treated with actoxumab + bezlotoxumab $(15.9 \%)$ or bezlotoxumab in monotherapy $(17.4 \%)$ than with placebo $(27.6 \%)(\mathrm{P}<0.0001$ and $\mathrm{P}=$ 0.0006 , respectively). Similar results have been reported in P002 study (53).

However, since these drugs are currently not available in European Union, it is impossible to include them in the following recommendations.

\section{Fecal microbiota transplantation (FMT) in prevention of CDI recurrence}

Fecal microbiota transplantation (FMT) has been recommended for many years as an alternative approach to treatment and prevention of CDI relapses. The main idea of FMT is to reconstruct normal gut microbiota in patients with iatrogenic changes in quality and quantity of intestinal flora who due to immunological disorders are unable to accomplish it spontaneously.

FMT is considered to be the most effective therapy for recurrent CDI. Metanalyses show that FMT is approximately 90 percent effective in prevention of CDI relapse $(54,55)$.

Nevertheless, to avoid potential negative consequences, the procedure of intestinal microbiota transfer needs standardization and strict quality control of transferred stool $(54,55)$.

1. The indication to FMT is the infection with $\mathrm{C}$. difficile that is resistant to antibiotics regardless of the number of CDI episodes (57).

As a consequence, FMT consideration/application is currently recommended also in the first CDI recurrence (54). FMT is contraindicated in patients with liver failure or food allergies and anaphylaxis (56).

2. The donors of intestinal bacteria should be young volunteers, who do not necessarily have to be recipient's relatives.

Persons aged 18-60 with BMI $>18 \mathrm{~kg} / \mathrm{m}^{2}$ and $<$ $30 \mathrm{~kg} / \mathrm{m}^{2}$ are preferred (56). Infectious diseases and pathological conditions that could negatively influence intestinal microbiota should be excluded through patient history, physical examination and wystąpienia kolejnych nawrotów choroby w stosunku do wankomycyny (19,7\% vs 35,5\%) (48).

3. Nowy kierunek badań i podejście terapeutyczne do leczenia CDI i zapobiegania nawrotom wyznaczają przeciwciała monoklonalne przeciw toksynom C. difficile.

Pierwszym zarejestrowanym przez FDA przeciwciałem wiążącym toksynę $\mathrm{B} C$. difficile jest bezlotoxumab. Badania kliniczne P001 i P002, potwierdzają skuteczność tego leku, zwłaszcza w połączeniu z przeciwciałem wiążącym toksynę A- actoxumabem, w profilaktyce nawrotów CDI (56). W badaniu P001, stwierdzono istotnie mniej nawrotów CDI w grupie otrzymującej actoxumab -plus-bezlotoxumab (15,9\%) oraz sam bezlotoxumab $(17,4 \%)$ w porównaniu z placebo $(27,6 \%)$ (odpowiednio $\mathrm{P}<0,0001$ and $\mathrm{P}=0,0006$ ). Podobne wyniki uzyskano w badaniu P002 (53).

Ze względu na brak dostępności tych leków, w chwili obecnej trudno zalecić stosowanie powyższych preparatów w aktualnych rekomendacjach.

\section{Zastosowanie transferu flory jelitowej w leczeniu nawrotów CDI.}

Poza powyższymi metodami leczenia i zapobiegania nawrotom CDI, od wielu lat rekomenduje się transfer flory bakteryjnej (fecal microbiota transferFMT). Głównym założeniem stosowania FMT jest rekonstrukcja prawidłowej flory jelitowej u osób z jatrogennymi zaburzeniami jakości i ilości tejże flory, które ze względu na przewlekłe zaburzenia immunologiczne nie są w stanie powrócić do prawidłowego stanu mikrobioty jelitowej siłami natury. FMT uważa się za najbardziej efektywną terapię nawrotowego CDI. Metaanalizy wskazują na skuteczność zapobiegania nawrotom CDI, sięgającą 90\% $(54,55)$.

Procedura transferu obcej flory jelitowej wymaga jednakże standaryzacji i kontrolowania jakości transferowanej flory, celem uniknięcia szkodliwych następstw tejże procedury $(54,55)$.

1. Wskazaniem do wykonania FMT jest oporne na leczenie antybiotykami zakażenie C. difficile, niezależnie od jego liczby incydentów (57).

Tak więc obecnie rekomenduje się rozważenie/zastosowanie FMT także w przypadku pierwszego nawrotu CDI (57).

Przeciwskazanie do leczenia CDI za pomocą transferu flory bakteryjnej, stanowi niewydolność wątroby u biorcy oraz alergia pokarmowa z odczynem anafilaktycznym (56).

2. Dawcą flory bakteryjnej powinien być zdrowy ochotnik, niekoniecznie powiązany rodzinnie $\mathrm{z}$ biorcą flory.

Preferuje się osoby w wieku 18-60 lat i BMI $>18$ $\mathrm{kg} / \mathrm{m}^{2} \mathrm{i}<30 \mathrm{~kg} / \mathrm{m}^{2}$ (56). U dawcy, należy wyklu- 
laboratory testing of blood and stool samples. Conditions that can potentially disrupt the normal gut flora and factors that disqualify the candidate from being a stool donor, as well as blood and stool tests required to be performed in the potential donor are listed in Tables XVIII and XIX. czyć choroby infekcyjne oraz stany chorobowe mogące wpływać niekorzystnie na stan flory jelitowej poprzez przeprowadzenie wywiadu, wykonanie badań krwi i stolca. Czynniki dyskwalifikujące dawcę oraz potencjalnie zaburzające stan flory jelitowej (dawca nierekomendowany) oraz panel badań krwi i stolca potencjalnego dawcy przedstawiono w tabelach XVIII i XIX.

Table XVIII. Conditions that can potentially disrupt the normal gut flora and factors that disqualify the candidate from being a stool donor (54)

Tabela XVIII. Stany chorobowe i czynniki dyskwalifikujące dawcę FTM oraz zaburzające stan flory jelitowej (54)

\begin{tabular}{|c|c|}
\hline $\begin{array}{l}\text { Factors disqualifying the candidate from being a stool } \\
\text { donor }\end{array}$ & $\begin{array}{l}\text { Conditions potentially disrupting the normal gut flora (not } \\
\text { recommended donor) }\end{array}$ \\
\hline $\begin{array}{l}\text { - HIV, HCV, HBV, HTLV- I or II infection } \\
\text { - Ongoing systemic infection } \\
\text { - Use of psychoactive drugs } \\
\text { - Risky sexual contacts } \\
\text { - } \text { Tissues and organs receipients } \\
\text { - Travelly in the tropics within last } 6 \text { months } \\
\text { - Exposure to biological material within last } 6 \text { months } \\
\text { - Non-medical procedures with skin disruption within } \\
\text { - last } 6 \text { months } \\
\text { - Gastro-intestinal infections within last } 2 \text { months } \\
\text { History of growth hormone, bovine insulin or } \\
\text { coagulation factors therapy }\end{array}$ & $\begin{array}{l}\text { - Chronic bowel diseases, including neoplasms or polyps } \\
\text { - Autoimmune diseases } \\
\text { - Neurodegenerative diseases } \\
\text { - Psychiatric disorders } \\
\text { - First-degree relatives of patients with polypomatosis or } \\
\text { colon cancer } \\
\text { - Use of systemic antibiotics, chemotherapy or } \\
\text { immunosuppresive treatment within last } 3 \text { months } \\
\text { - Daily use of proton pump inhibitors within last } 3 \\
\text { months }\end{array}$ \\
\hline
\end{tabular}

\begin{tabular}{|c|c|}
\hline Choroby i czynniki dyskwalifikujące dawcę & $\begin{array}{c}\text { Stany zaburzające florę jelitową (dawca } \\
\text { nierekomendowany) }\end{array}$ \\
\hline $\begin{array}{l}\text { - Zakażenie HIV, HCV, HBV, HTLV- I i II } \\
\text { - } \quad \text { Aktualnie toczące się zakażenie ogólnoustrojowe } \\
\text { - Stosowanie środków odurzających } \\
\text { - Ryzykowne zachowania seksualne } \\
\text { - } \quad \text { Biorcy przeszczepów tkanek i narządów } \\
\text { - Niedawno zakończony pobyt w szpitalu } \\
\text { - Podróże do strefy tropikalnej bez właściwej profilakty- } \\
\text { ki w ostatnich } 6 \text { miesiącach } \\
\text { - Narażenie na materiał biologiczny w ostatnich } 6 \text { miesiącach } \\
\text { - Zabiegu niemedyczne z przerwaniem ciągłości tkanek } \\
\text { - } \text { - Zastatnich } 6 \text { miesiącach } \\
\text { - } \text { sąąacach } \\
\text { - Przebyte leczenie hormonem wzrostu, insuliną bydlęcą, } \\
\text { czynnikami krzepnięcia }\end{array}$ & $\begin{array}{l}\text { - Przewlekłe choroby przewodu pokarmowego w tym } \\
\text { nowotwory i polipy } \\
\text { - Choroby autoimmunologiczne } \\
\text { - Choroby neurodegeneracyjne } \\
\text { - Choroby psychiczne } \\
\text { - Pierwszy stopień pokrewieństwa w stosunku do osób z } \\
\text { polipowatością lub rakiem jelita grubego } \\
\text { - Systemowa antybiotykoterapia, chemioterapia lub le- } \\
\text { - czenie immunosupresyjne w ciągu ostatnich } 3 \text { miesięcy } \\
\text { - Codzienne stosowanie inhibitorów pompy protonowej } \\
\text { w ciągu ostatnich } 3 \text { miesięcy }\end{array}$ \\
\hline
\end{tabular}

3. Preparation of the sample procedure

- The stool that is to be transferred by FMT has to be retrieved from the last stool (up to 6 hours since defecation) or it can also be obtained immediately after defrost from frozen samples stored in $-80^{\circ} \mathrm{C}$. Single procedure involves donation of at least $50 \mathrm{~g}$ of stool.

- Feces should be dissolved in $100 \mathrm{ml}$ of saline if given through stomach probe or in $300 \mathrm{ml}$ of saline if given directly through intracolon injection (54).
3. Procedura przygotowania materiału do transferu.

- Materiał przygotowywany do FMT powinien pochodzić ze świeżego wypróżnienia (do 6 godzin od defekacji) zakwalifikowanego dawcy lub $\mathrm{z}$ puli mrożonej w temperaturze minus $80{ }^{\circ} \mathrm{C}$, bezpośrednio po rozmrożeniu. Do jednorazowego transferu potrzebne jest co najmniej $50 \mathrm{~g}$ stolca.

- Pozyskany materiał powinien być rozcieńczony w $100 \mathrm{ml}$ soli fizjologicznej, jeśli będzie podawany drogą sondy żołądkowej lub $300 \mathrm{ml}$ - jeśli zaplanowano podanie do jelita grubego (54). 
Table XIX. Blood and stool tests required to be performed in the potential donor before FMT procedure (57) Tabela XIX. Panel badań rekomendowanych u dawcy flory bakteryjnej (57)

\begin{tabular}{|l|l|}
\hline \multicolumn{1}{|c|}{ Blood tests } & \multicolumn{1}{c|}{ Stool tests } \\
\hline - HAV IgM, HBsAg, anti-HCV, anti- HEV * & $\bullet$ GDH + A/B toxins \\
- VDRL & $\bullet$ Stool culture** \\
- Complete blood count & $\bullet \quad$ Antibiotic resistance assessment*** \\
& $\bullet \quad$ Serological testing for noro-, rota- and adenoviruses \\
& $\bullet \quad$ Stool testing for the presence of parasites \\
\hline
\end{tabular}

* - indicated only in certain situations (np. potential epidemic threat in a particular area)

** - stool culture should include assessment of the presence of: Salmonella, Shigella, Campylobacter, enterotoxic E. coli strains, Yersinia; Vibrio cholerae - in selected cases

*** - assessment of VRE, MRSA, ESBL, and resistance to carbapenems in Enterobacteriacae

$* * * *-H$. pylori antigen assessment is indicated when FMT is chosen to be given through stomach probe

\begin{tabular}{|l|l|}
\hline \multicolumn{1}{|c|}{ Badania krwi } & \multicolumn{1}{c|}{ Badania stolca } \\
\hline $\begin{array}{l}|c| \\
\text { - HAV IgM, HBsAg, anty- HCV, anty- HEV* }\end{array}$ & $\bullet$ GDH + toksyna Cl. difficile \\
- Morfologia krwi & $\bullet$ Posiew kału** \\
- Kreatynina, ALT* & $\bullet$ Ocena oporności antybiotyków*** \\
& $\bullet$ Badanie serologiczne w kierunku Noro-, Rota-, Adeno- \\
& wirusów \\
& $\bullet$ Badanie kału w kierunku obecności pasożytów \\
\hline
\end{tabular}

* - badania wskazane tylko w wybranych sytuacjach (np. zagrożenie epidemiologiczne na danym terenie);

** - posiew kału powinien obejmować badania w kierunku obecności: Salmonella, Shigella, Campylobacter, szczepy toksyczne E. coli, Yersinia; Vibrio cholerae - w uzasadnionych przypadkach;

*** - ocena dotyczy VRE, MRSA, ESBL, oporności na karbapenemy w przypadku Enterobacteriacae;

**** - ocena obecności antygenu H. pylori w kale zalecana jest w przypadkach FMT podawanego przez sondę żołądkową.

- If samples obtained from the donor are to be frozen, they should be divided into portions and stored with the addition of $10 \%$ glycerol in $-80^{\circ} \mathrm{C}$ (recommended temperature), for up to 6 months; if stored in $-20^{\circ} \mathrm{C}$, they can remain frozen for at most 30 days (56).

4. Fecal microbiota transfer involves the choice of administration route, preparation of the recipient and the procedure itself.

- FMT can be performed with the use of stomach or duodenal probe, through PEG or jejunostomy (54).

- It has to be noted that in case of FMT through stomach probe (the most common route), patient has to be seated upwards during the whole procedure to avoid the risk of transferred material aspiration.

- If FMT is to be given into colon, intracaecal administration with the use of colonoscope is preferred $(54,56)$. Intestinal flora solution can be given as a retention enema, however, it is quickly excreted and does not bring satisfactory results.

5. Preparation of the recipient depends on the choice of administration route.
- Jeśli materiał od dawcy zostaje zamrożony, powinien być przygotowany w porcjach $\mathrm{z}$ dodatkiem $10 \%$ glicerolu. Materiał zamrożony do $-80{ }^{\circ} \mathrm{C}$ (temperatura zalecana), może być przechowywany przez 6 miesięcy; w przypadku przechowywania w temp $-20^{\circ} \mathrm{C}$, maksymalny czas magazynowania wynosi 30 dni (56).

4. Procedura transferu mikrobioty jelitowej obejmuje wybór drogi podania, przygotowanie biorcy oraz samo podanie materiału do przewodu pokarmowego.

- FMT należy podać gastroduodenoskopem głęboko do dwunastnicy (preferowana metoda podania) ewentualnie przez sondę dodwunastniczą lub dożołądkową, można także przez PEG lub jejunostomię (54).

- Po podaniu FMT i usuwaniu gastroduodenoskopu, sondy dodwunastniczej czy dożołądkowej należy ją dokładnie przepłukać w żołądku tak, aby uniknąć przedostania się resztek FTM do jamy ustnej. Należy pamiętać, że w przypadku użycia sondy dodwunastniczej czy dożołądkowej (mniej korzystna forma podania), pacjent musi być zdolny do utrzymania pozycji siedzącej w czasie całego zabiegu, celem uniknięcia zachłyśnięcia się transferowana treścią i/lub sprowokowania wymiotów. 
- In every case the procedure should be performed at least 24 hours after the end of antibiotic treatment for CDI.

- FMT should also be proceeded by administration of two PPI doses (the first on the preceding day and the second in the morning on the scheduled day of the procedure) (54). One dose of metoclopramide right before the transfer can also be considered.

- FMT as retention enema should be proceeded by cleansing enema in order to flush out the colon (54).

\section{RECOMMENDATIONS CDI PREVENTION}

In order to prevent $C$. difficile infections, it is recommended to $(1,61,62)$ :

1. Avoid the use of antibiotics which pose the highest risk of CDI development

2. Shorten the duration of antibiotic treatment to the minimum possible

3. Consider administration of Saccharomyces boulardii during exposure to antibiotics in hospitalized patients.

In 2018 the results of a multicenter, prospective, placebo-controlled trial were presented which showed that the use of $5 \times 10^{9} \mathrm{~S}$. boulardi twice daily resulted in a decrease of CDI prevalence $(1.5 \%$ versus $3.6 \%$; OR $=0.06)$ in hospitalized patient with exposure to antibiotics (63). Moreover, a research on the use of non-toxigenic $C$. difficile M3 strain in prevention of CDI relapses is ongoing (64), however, due to limited sample size inclusion of this approach in the recommendations warrants further investigation.

4. Shorten the duration of hospitalization (especially in patients from high risk groups) to minimum possible

5. Avoid placing high risk patients in rooms where patients with CDI were previously hospitalized.

Contamination of healthcare workers' hands with bacterial spores as well as contamination of the utensils and surfaces play a major role in the transmission of $C$. difficile infection to a patient (57). One of the important factors contributing to the development of CDI in hospital setting is hospitalization in a room previously occupied by a person with CDI (58-60). Separate rooms with their own toilet and isolation of patients with CDI are thus recommended.

6. Consider using/use primary or secondary CDI prophylaxis.

Secondary CDI prophylaxis involves vancomycin administration. The use of vancomycin in patients with history of CDI treatment who are exposed to
- W przypadku wyboru drogi podania do jelita grubego, preferowaną metodą jest podanie materiału dokątniczo, przez kolonoskop $(54,56)$. Podawanie roztworu flory jelitowej drogą głębokiej wlewki doodbytniczej jest możliwe, jednak często wiąże się z szybkim wydaleniem materiału i zabieg nie przynosi oczekiwanego efektu.

5. Sposób przygotowania biorcy do zabiegu, zależy od wybranej drogi podania materiału.

- W każdym przypadku zabieg powinien być wykonywany co najmniej 24 godziny po zakończeniu antybiotykoterapii CDI.

- Transfer flory bakteryjnej do żołądka powinien być poprzedzony podaniem 2 dawek IPP (pierwsza wieczorem $\mathrm{w}$ dniu poprzedzającym zabieg, druga - rano w dniu zabiegu) (54). Można rozważyć także zastosowanie jednej dawki metoklopramidu bezpośrednio przed zabiegiem.

- Natomiast w przypadku FMT w formie głębokiej wlewki doodbytniczej zaleca się wykonanie lewatywy przed zabiegiem, celem oczyszczenia okrężnicy (54).

\section{REKOMENDACJE DOTYCZĄCE ZAPOBIEGANIA CDI}

Celem zapobiegania zakażeniom o etiologii $\mathrm{Clo}$ stridium difficile zaleca się $(1,61,62)$ :

1. Unikanie stosowania antybiotyków o największym ryzyku oporności CD

2. Skracanie antybiotykoterapii do niezbędnego minimum

3. Stosowanie preparatów Saccharomyces bulardi $\mathrm{w}$ trakcie antybiotykoterapii u hospitalizowanych pacjentów.

W 2018 roku ukazały się wyniki wieloośrodkowego, prospektywnego badania z grupą porównawczą, w którym wykazano, że stosowanie $S$. boular$d i \mathrm{w}$ dawce $5 \times 10^{9} 2$ razy dziennie zmniejszyło częstość $(1,5 \%$ vs $3,6 \%, \mathrm{OR}=0,06)$ występowania CDI $\mathrm{u}$ chorych hospitalizowanych leczonych antybiotykami (63). Ponadto trwają badania nad zastosowaniem nietoksynotwórczego szczepu $C$. difficile M3 - w zapobieganiu nawrotom CDI (64). Z powodu zbyt małej grupy chorych, u których zastosowano tę profilaktykę, rekomendowanie tej metody wymaga dalszych dowodów naukowych.

4. Skracanie hospitalizacji (szczególnie chorych z grup ryzyka) do niezbędnego minimum

5. Unikanie hospitalizacji chorych $\mathrm{z}$ grup ryzyka w salach, w których byli leczeni wcześniej chorzy z CDI.

Zakażenie $C$. difficile najczęściej przenoszone jest na pacjenta przez zanieczyszczone sporami ręce personelu medycznego oraz zanieczyszczone 
systemic antibiotics or need hospitalization (within 90 days after CDI episode) was proven to reduce the risk of CDI recurrence (65). Dose of $125 \mathrm{mg}$ orally once per day is recommended for a whole period of antibiotic treatment and for 5 days after its end (66).

Some authors recommend the use of primary CDI prophylaxis in patients at high risk of CDI development and high risk for severe disease or death (e.g. patients with oncohematological disorders). However, the recommendations are unequivocal since randomized clinical trials in these populations are lacking and the use of primary CDI prophylaxis needs individual consideration. Nevertheless, the results of cohort studies in patients after hematopoietic stem cell transplantation are encouraging (67).

7. Supplementation of vitamin D3 deficiency is recommended in patients from high risk groups for CDI, since vitamin D3 deficiency has been proven to be associated not only with community-acquired CDI diarrhea, but also with more severe course of the disease $(27,68)$.

8. Isolation of patients with $\mathrm{CD}$ diarrhea. The recommended isolation time is until 48 hours after resolution of the symptoms (54).

9. Use of disposable gloves when managing patients with CDI and their personal items, underwear in particular.

10. Wash hands with soap and water before and after use of disposable gloves.

11. Frequent hand and body wash should be recommended to patients in order to remove the CD spores from the skin.

12. Disinfection of the rooms, where patients with CDI stayed, with methods effective against spores (chlorine-based sporicides, fumigation).

\section{REFERENCES}

1. McDonald LC, Gerding DN, Johnson S, et al. Clinical Practice Guidelines for Clostridium difficile Infection in Adults and Children: 2017 Update by the Infectious Diseases Society of America (IDSA) and Society for Healthcare Epidemiology of America (SHEA). Clin Infect Dis. 2018 19;66(7):e1-48.

2. Lawson PA, Citron DM, Tyrrell KL, Finegold SM. Reclassification of Clostridium difficile as Clostridioides difficile (Hall and O'Toole 1935) Prévot 1938. Anaerobe. 2016 Aug;40:95-9.

3. Oren A, Rupnik M. Clostridium difficile and Clostridioides difficile: Two validly published and correct names. Anaerobe. 2018 Aug;52:125-6. sprzęty znajdujące się w środowisku szpitalnym (57). Jednym $z$ ważnych czynników wystąpienia CDI w warunkach szpitalnych jest hospitalizacja w sali, w której poprzednio był leczony pacjent z CDI (58-60). Rekomendowane jest zatem wydzielenie sal do leczenia CDI, izolacja pacjentów $\mathrm{w}$ tychże salach z wydzieloną toaletą, niedostępną dla innych pacjentów.

6. Rozważenie/ stosowanie profilaktyki swoistej CDI: wtórnej i pierwotnej.

Obecnie wskazuje się na konieczność rozważenia stosowania wankomycyny w profilaktyce wtórnej CDI. Wykazano, że u chorych po leczeniu CDI, którzy otrzymują antybiotykoterapię systemową lub zostają hospitalizowani (w ciągu 90 dni po pierwotnym incydencie CDI) zastosowanie wankomycyny przyczynia się do zmniejszenia ryzyka nawrotów (65). W profilaktyce wtórnej zaleca się stosowanie $125 \mathrm{mg}$ wankomycyny p.o 1x na dobę przez cały czas stosowania antybiotyku systemowego oraz przez 5 dni po jego zakończeniu (66).

Niektórzy badacze skłaniają się ponadto do stosowania pierwotnej profilaktyki CDI u chorych z dużym ryzykiem wystąpienia tej choroby oraz istotnym ryzykiem jej ciężkiego przebiegu a nawet zgonu (np. chorzy hematoonkologiczni). Rekomendacje w tym zakresie nie są dotychczas jednoznaczne ze względu na brak badań randomizowanych w tych grupach chorych, jednakże, zastosowanie pierwotnej profilaktyki CDI w indywidualnych przypadkach wymaga rozważenia (67).

7. Uzupełnianie niedoborów witaminy $\mathrm{D}$ zaleca się u chorych z grup ryzyka CDI, gdyż jak wykazano jej niedobór wiąże się nie tylko z ryzykiem wystąpienia biegunki w przebiegu CDI w środowisku pozaszpitalnym, ale także $\mathrm{z}$ cięższym przebiegiem CDI $(27,68)$.

8. Izolację chorych z biegunką o etiologii CDI. Zalecany czas izolacji to cały okres trwania biegunki oraz 48 godzin po jej ustąpieniu (54).

9. Stosowanie jednorazowych rękawiczek przy kontakcie z chorym na CDI oraz jego przedmiotami osobistymi, szczególnie bielizną.

10. Mycie rąk wodą z mydłem przed i po zastosowaniu rękawiczek.

11. Zalecanie pacjentom częstego mycia rąk oraz kąpieli celem usunięcia spor CD ze skóry.

12. Stosowanie dezynfekcji pomieszczeń, w których przebywali chorzy na CDI, metodami niszczącymi spory CD. 
4. Czarkowski M, Cielebąk E, Kondej B, Sadłocha A. Choroby zakaźnej i zatrucia w Polsce w 2018 roku. NIZP-PZH i GIS, Warszawa 2019. Dostępne na http://wwwold.pzh.gov.p1/oldpage/epimeld/2018/ Ch_2018.pdf

5. Centers for Disease Control and Prevention. Severe Clostridium difficile-associated disease in populations previously at low risk-four states, 2005. MMWR Morb Mortal Wkly Rep 2005; 54:1201-5.

6. Dial S, Delaney JA, Barkun AN, Suissa S. Use of gastric acid-suppressive agents and the risk of community-acquired Clostridium difficileassociated disease. JAMA 2005; 294:2989-95.

7. James AH, Katz VL, Dotters DJ, Rogers RG. Clostridium difficile infection in obstetric and gynecologic patients. South Med J 1997; 90:88992.

8. Johal SS, Hammond J, Solomon $\mathrm{K}$, et al. Clostridium difficile associated diarrhoea in hospitalised patients: onset in the community and hospital and role of flexible sigmoidoscopy. Gut 2004; 53:673-7.

9. Kyne L, Merry C, O'Connell B, et al. Communityacquired Clostridium difficile infection. J Infect 1998; 36:287-8.

10. Terhes G, Urbán E, Sóki J, et al. Communityacquired Clostridium difficile diarrhea caused by binary toxin, toxin $\mathrm{A}$, and toxin $\mathrm{B}$ gene-positive isolates in Hungary. J Clin Microbiol 2004; 42:4316-8.

11. Hensgens MP, Goorhuis A, Dekkers OM, et al. Time interval of increased risk for Clostridium difficile infection after exposure to antibiotics. $\mathrm{J}$ Antimicrob Chemother 2012; 67:742-8.

12. Pépin J, Saheb N, Coulombe MA, et al. Emergence of fluoroquinolones as the predominant risk factor for Clostridium difficile-associated diarrhea: a cohort study during an epidemic in Quebec. Clin Infect Dis 2005; 41:1254-60.

13. LooVG, PoirierL, Miller MA, etal.Apredominantly clonal multi-institutional outbreak of Clostridium difficile-associated diarrhea with high morbidity and mortality. N Engl J Med 2005; 353:2442-9.

14. Muto CA, Pokrywka M, Shutt K, et al. A large outbreak of Clostridium difficile-associated disease with an unexpected proportion of deaths and colectomies at a teaching hospital following increased fluoroquinolone use. Infect Control Hosp Epidemiol 2005; 26:273-80.

15. Johnson S, Samore MH, Farrow KA, et al. Epidemics of diarrhea caused by a clindamycinresistant strain of Clostridium difficile in four hospitals. N Engl J Med 1999; 341:1645-51.
16. Thibault A, Miller MA, Gaese C. Risk factors for the development of Clostridium difficile-associated diarrhea during a hospital outbreak. Infect Control Hosp Epidemiol 1991; 12:345-8.

17. Chitnis AS, Holzbauer SM, Belflower RM, et al. Epidemiology of community-associated Clostridium difficile infection, 2009 through 2011. JAMA Intern Med 2013; 173:1359-67.

18. Anand A, Glatt AE. Clostridium difficile infection associated with antineoplastic chemotherapy: a review. Clin Infect Dis 1993; 17:109-13.

19. Morales Chamorro R, Serrano Blanch R, Méndez Vidal MJ, et al. Pseudomembranous colitis associated with chemotherapy with 5-fluorouracil. Clin Transl Oncol 2005; 7:258-61.

20. Bilgrami S, Feingold JM, Dorsky D, et al. Incidence and outcome of Clostridium difficile infection following autologous peripheral blood stem cell transplantation. Bone Marrow Transplant 1999; 23:1039-42.

21. Gorschlüter M, Glasmacher A, Hahn C, et al. Clostridium difficile infection in patients with neutropenia. Clin Infect Dis 2001; 33:786-91.

22. Sanchez T, Brooks J, Sullivan P, et al. Bacterial diarrhea in persons with HIV infection, United States, 1992-2002. Clin Infect Dis 2005; 41:16217.

23. Bliss DZ, Johnson S, Savik K, et al. Acquisition of Clostridium difficile and Clostridium difficileassociated diarrhea in hospitalized patients receiving tube feeding. Ann Intern Med 1998; 129:1012-9.

24. Negrón ME, Rezaie A, Barkema HW, et al. Ulcerative colitis patients with Clostridium difficile are at increased risk of death, colectomy, and postoperative complications: a population-based inception cohort study. Am J Gastroenterol 2016; 111:691-704.

25. Razik R, Rumman A, Bahreini Z, McGeer A, Nguyen GC. Recurrence of Clostridium difficile infection in patients with inflammatory bowel disease: the RECIDIVISM Study. Am J Gastroenterol 2016; 111:1141-6.

26. Peng JC, Shen J, Zhu Q, Ran ZH. The impact of Clostridum difficile on surgical rate among ulcerative colitis patients: a systemic review and meta-analysis. Saudi J Gastroenterol 2015; 21:208-12.

27. Sahay T, Ananthakrishnan AN. Vitamin D deficiency is associated with community-acquired Clostridium difficile infection: a case-control study. BMC Infect Dis 2014; 14:661.

28. Phatharacharukul P, Thongprayoon C, Cheungpasitporn $\mathrm{W}$, et al. The risks of incident and recurrent Clostridium difficile-associated diarrhea in chronic kidney disease and end-stage kidney 
disease patients: a systematic review and metaanalysis. Dig Dis Sci 2015; 60:2913-22.

29. Thongprayoon C, Cheungpasitporn W, Phatharacharukul $\mathrm{P}$, et al. Chronic kidney disease and end-stage renal disease are risk factors for poor outcomes of Clostridium difficile infection: a systematic review and meta-analysis. Int J Clin Pract 2015; 69:998-1006.

30. Miller MA, Louie T, Mullane K, et al. Derivation and validation of a simple clinical bedside score (ATLAS) for Clostridium difficile infection which predicts response to therapy. BMC Infect Dis 2013; 13:148.

31. Chopra T, Miller M, Severson R, et al. ATLAS-A Bedside Scoring System Predicting Mortality Due to Clostridium Difficile Infection (CDI) in Elderly Hospitalized Patients. IDSA Conference 2010. https://idsa.confex.com/ idsa/2010/webprogram/Paper4263.html

32. Skomorochow E, Pico J. Toxic Megacolon. StatPearls [Internet]. Treasure Island (FL): StatPearls Publishing; 2019-2019 Oct 9.

33. Kwon JH, Olsen MA, Dubberke ER. The morbidity, mortality, and costs associated with Clostridium difficile infection. Infect Dis Clin North Am 2015; 29:123-34.

34. Vallabhaneni S, Almendares O, Farley MM, et al. Epidemiology and factors associated with candidaemia following Clostridium difficile infection in adults within metropolitan Atlanta, 2009-2013. Epidemiol Infect 2016; 144:1440-4.

35. Fekety R, McFarland LV, Surawicz CM, et al. Recurrent Clostridium difficile diarrhea: characteristics of and risk factors for patients enrolled in a prospective, randomized, doubleblinded trial. Clin Infect Dis 1997; 24:324-33.

36. McFarland LV, Surawicz CM, Rubin M, et al. Recurrent Clostridium difficile disease: epidemiology and clinical characteristics. Infect Control Hosp Epidemiol 1999; 20:43-50.

37. Garey KW, Sethi S, Yadav Y, DuPont HL. Metaanalysis to assess risk factors for recurrent Clostridium difficile infection. J Hosp Infect 2008; 70:298-304.

38. Olsen MA, Yan Y, Reske KA, et al. Recurrent Clostridium difficile infection is associated with increased mortality. Clin Microbiol Infect 2015; 21:164-70.

39. Lewis SJ, Heaton KW. Stool form scale as a useful guide to intestinal transit time. Scand J Gastroenterol 1997; 32:920-4.

40. Burnham CA, Carroll KC. Diagnosis of Clostridium difficile infection: an ongoing conundrum for clinicians and for clinical laboratories. Clin Microbiol Rev 2013; 26:604-30.
41. Wilcox MH. Overcoming barriers to effective recognition and diagnosis of Clostridium difficile infection. Clin Microbiol Infect 2012; 18(Suppl 6):13-20.

42. Mullane KM, Miller MA, Weiss K, et al. Efficacy of fidaxomicin versus vancomycin as therapy for Clostridium difficile infection in individuals taking concomitant antibiotics for other concurrent infections. Clin Infect Dis 2011; 53:440-7.

43. Koo HL, Koo DC, Musher DM, DuPont HL. Antimotility agents for the treatment of Clostridium difficile diarrhea and colitis. Clin Infect Dis 2009; 48:598-605.

44. Wilcox MH, Howe R. Diarrhoea caused by Clostridium difficile: response time for treatment with metronidazole and vancomycin. J Antimicrob Chemother 1995; 36:673-9.

45. Johnson S, Louie TJ, Gerding DN, et al; Polymer Alternative for CDI Treatment (PACT) Investigators. Vancomycin, metronidazole, or tolevamer for Clostridium difficile infection: results from two multinational, randomized, controlled trials. Clin Infect Dis 2014; 59:345-54.

46. Zar FA, Bakkanagari SR, Moorthi KM, Davis MB. A comparison of vancomycin and metronidazole for the treatment of Clostridium difficile-associated diarrhea, stratified by disease severity. Clin Infect Dis 2007; 45:302-7.

47. Louie TJ, Miller MA, Mullane KM, et al; OPT80-003 Clinical Study Group. Fidaxomicin versus vancomycin for Clostridium difficile infection. $\mathrm{N}$ Engl J Med 2011; 364:422-31.

48. Cornely OA, Crook DW, Esposito R, et al; OPT80-004 Clinical Study Group. Fidaxomicin versus vancomycin for infection with Clostridium difficile in Europe, Canada, and the USA: a double-blind, non-inferiority, randomised controlled trial. Lancet Infect Dis 2012; 12:281-9.

49. Siegfried J, Dubrovskaya Y, Flagiello T, et al. Initial therapy for mild to moderate Clostridium difficile infection. Infect Dis Clin Pract 2016; 24:210-6.

50. Rokas KE, Johnson JW, Beardsley JR, et al. The Addition of intravenous metronidazole to oral vancomycin is associated with improved mortality in critically ill patients with Clostridium difficile infection. Clin Infect Dis 2015; 61:934-41.

51. Neal MD, Alverdy JC, Hall DE, et al. Diverting loop ileostomy and colonic lavage: an alternative to total abdominal colectomy for the treatment of severe, complicated Clostridium difficile associated disease. Ann Surg 2011; 254:423-7; discussion 427-9.

52. Garey KW, Ghantoji SS, Shah DN, et al. A randomized, double-blind, placebo-controlled pilot study to assess the ability of rifaximin 
to prevent recurrent diarrhoea in patients with Clostridium difficile infection. J Antimicrob Chemother 2011; 66:2850-5

53. FDA Panel Recommends Approval of C. difficile Drug Bezlotoxumab [Internet]. Managed Care magazine. 2016 [cited 2019 Oct 27]. Available from: https://www.managedcaremag.com/news/ fda-panel-recommends-approval-c-difficile-drugbezlotoxumab

54. Cammarota G, Ianiro G, Kelly CR et al. International consensus conference on stool banking for faecal microbiota transplantation in clinical practice. Gut. 2019 Sep 28. pii: gutjnl-2019-319548. doi: 10.1136/gutjnl-2019-319548. [Epub ahead of print]

55. van Beurden $\mathrm{YH}$, de Groot PF, van Nood E et al. Complications, effectiveness, and long term followup of fecal microbiota transfer by nasoduodenal tube for treatment of recurrent Clostridium difficile infection. United European Gastroenterol J. 2017; $5(6): 868-879$.

56. Mullish BH, Quraishi MN, Segal JP, et al. Introduction to the joint British Society of Gastroenterology (BSG) and Healthcare Infection Society (HIS) faecal microbiota transplant guidelines.J Hosp Infect. 2018 Oct;100(2):130-132

57. Bobulsky GS, Al-Nassir WN, Riggs MM, et al. Clostridium difficile skin contamination in patients with C. difficile-associated disease. Clin Infect Dis 2008; 46:447-50

58. Shaughnessy MK, Micielli RL, DePestel DD, et al. Evaluation of hospital room assignment and acquisition of Clostridium difficile infection. Infect Control Hosp Epidemiol 2011; 32:201-6.

59. Walker AS, Eyre DW, Wyllie DH, et al. Characterisation of Clostridium difficile hospital ward-based transmission using extensive epidemiological data and molecular typing. PLoS Med 2012; 9:e1001172.

60. Eyre DW, Cule ML, Wilson DJ, et al. Diverse sources of C. difficile infection identified on whole-genome sequencing. N Engl J Med 2013; 369:1195-205.

61. Song JH, Kim YS. Recurrent Clostridium difficile Infection: Risk Factors, Treatment, and Prevention. Gut Liver. 2019 Jan 15;13(1):16-24

62. Madoff SE, Urquiaga M, Alonso CD, Kelly CP. Prevention of recurrent Clostridioides difficile infection: A systematic review of randomized controlled trials.Anaerobe. 2019 Sep 4:102098. doi: $10.1016 / \mathrm{j}$.

63. Carstensen JW, Chehri M, Schønning K, et al. Use of prophylactic Saccharomyces boulardii to prevent Clostridium difficile infection in hospitalized patients: a controlled prospective intervention study. Eur J Clin Microbiol Infect Dis. 2018 Aug;37(8):1431-1439

64. Gerding DN, Meyer T, Lee C, et al. Administration of spores of nontoxigenic Clostridium difficile strain M3 for prevention of recurrent C. difficile infection: a randomized clinical trial.JAMA. 2015 May 5;313(17):1719-27

65. Carignan A, Poulin S, Martin P, et al. Efficacy of secondary prophylaxis with vancomycin for preventing recurrent Clostridium difficile infections. Am J Gastroenterol 2016; 111:1834-40.

66. Johnson SW, Brown SV, Priest DH. Effectiveness of Oral Vancomycin for Prevention of Healthcare Facility-Onset Clostridioides difficile Infection in Targeted Patients During Systemic Antibiotic Exposure. Clin Infect Dis. 2019 Sep 27.

67. Ganetsky A, Han JH, Hughes ME, et al. Oral Vancomycin Prophylaxis Is Highly Effective in Preventing Clostridium difficile Infection in Allogeneic Hematopoietic Cell Transplant Recipients. Clin Infect Dis. 2019 May 30;68(12):2003-9.

68. Wang WJ, Gray S, Sison C, et al. Low vitamin D level is an independent predictor of poor outcomes in Clostridium difficile-associated diarrhea. Therap Adv Gastroenterol 2014; 7:14-9.

Received: 10.02 .2020

Accepted for publication: 12.03.2020

Otrzymano: 10.02.2020 r.

Zaakceptowano do publikacji: $12.03 .2020 \mathrm{r}$.

\section{Adres do korespondencji:}

\section{Address for correspondence:}

Anna Piekarska

Klinika Chorób Zakaźnych i Hepatologii UM w Łodzi ul. Kniaziewicza 1/5, 91-347 Łódź

e-mail: annapiekar@gmail.com 